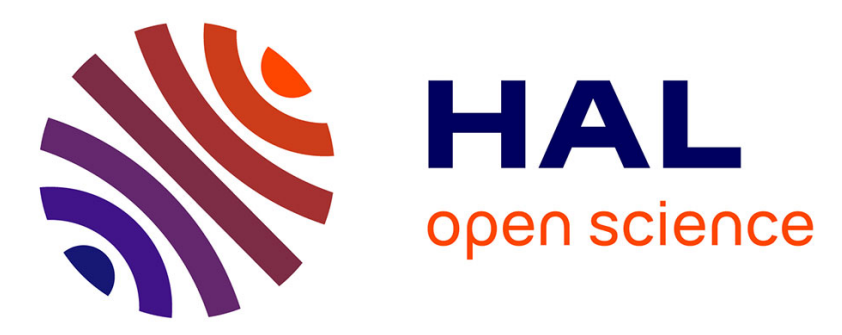

\title{
Depollution of mining effluents: innovative mobilization of plant resources
}

Andrii Stanovych, Muriel Balloy, Tomasz Olszewski, Eddy Petit, Claude Grison

\section{- To cite this version:}

Andrii Stanovych, Muriel Balloy, Tomasz Olszewski, Eddy Petit, Claude Grison. Depollution of mining effluents: innovative mobilization of plant resources. Environmental Science and Pollution Research, 2019, 26, pp.19327-19334. 10.1007/s11356-019-05027-y • hal-02390370

\section{HAL Id: hal-02390370 \\ https://hal.science/hal-02390370}

Submitted on 13 Oct 2020

HAL is a multi-disciplinary open access archive for the deposit and dissemination of scientific research documents, whether they are published or not. The documents may come from teaching and research institutions in France or abroad, or from public or private research centers.
L'archive ouverte pluridisciplinaire HAL, est destinée au dépôt et à la diffusion de documents scientifiques de niveau recherche, publiés ou non, émanant des établissements d'enseignement et de recherche français ou étrangers, des laboratoires publics ou privés. 


\title{
Depollution of mining effluents: innovative mobilization of plant resources
}

\author{
Andrii Stanovych $^{1} \cdot$ Muriel Balloy $^{1} \cdot$ Tomasz K. Olszewski $^{2} \cdot$ Eddy Petit $^{3} \cdot$ Claude Grison $^{1}$ (D)
}

\begin{abstract}
Based on the ability of some specific aquatic plants to concentrate metals in their roots, we propose an innovative biosorption system to clean up mining effluents. The system we propose represents an interesting solution to an important environmental problem, the decontamination of metal-polluted water and prevention of dispersal of metals into the environment. The solution presented is a form of ecological recycling of $\mathrm{Zn}$, an essential primary metal in many industrial applications. Finally, the methodology developed is a sustainable way of managing the biomass from eradication or control of invasive plants.
\end{abstract}

Keywords Aquatic pollution · Metal-contaminated mining effluents · Water management · Biosorption · Plant-based filter system $\cdot$ Sustainable and eco-friendly processes

\section{Introduction}

As a vital natural resource, water is also a driving force of economic and social development. Domestic, agricultural, and industrial activities, in addition to factors such as climate change, demographic pressure, and overconsumption of water, constitute a real threat to drinking water reserves, rivers, water tables, floodplains, irrigated agricultural lands, water for livestock, and habitat for fish. Importantly, water is the first natural resource affected by climate change (Crimmins et al. 2016; Cisneros et al. 2014). The European Parliament has established a set of measures to improve water quality (Directive 2000/60/EC). In particular, this directive presents a strategy for the control of pollution by substances of most concern. In that respect, control of contamination with metals

Responsible editor: Philippe Garrigues

Claude Grison

claude.grison@cnrs.fr

1 Laboratory of Bio-inspired Chemistry and Ecological Innovations, UMR 5021 CNRS - University of Montpellier, Montpellier, France

2 Faculty of Chemistry, Wrocław University of Science and Technology, Wybrzeże Wyspiańskiego 27, 50-370 Wrocław, Poland

3 Institut Européen des Membranes, CNRS - University of Montpellier, Ecole Nationale Supérieure de Chimie de Montpellier, Montpellier, France is considered to be one of the top priorities (Decision No 2455/2001/EC).

Despite stricter regulations (NOR: ATEP9870017A 2019), industry is still responsible for the majority of direct discharges of wastes in water. In this respect, mining activities, and the metallurgical and chemical industries based on them, remain at the origin of a large proportion of environmental pollutants. Because of their interesting physical properties (electrical and thermal conduction, hardness, malleability, catalytic properties, etc.), metals are widely used by industry. High demand for metals is responsible for the fact that metalliferous deposits have been exploited for a long time. For this reason, mining activity still causes metals to be dispersed into the environment. Not only soils but also aquatic environments become contaminated by mining effluents.

Overflow of mine-settling ponds leads to the formation of runoff water that permanently disperses the metal elements into the environment (Luoma and Rainbow 2008). The problem is all the more important as many mines are no longer exploited, and are often abandoned (Passariello et al. 2002). The Cévennes mines (Gard, France) are an excellent illustration of such a situation, where abandonment of mines has led to the contamination of rivers with zinc ( $\mathrm{Zn})$, cadmium (Cd), and lead $(\mathrm{Pb})$ (Saunier et al. 2013). The solutions so far put in place exacerbate the problem since they generate toxic sludge, which is very difficult to manage. The intensity of summer droughts in the region, however, suggests that it is crucial to protect drinking water resources. 
Another source of pollution, particularly affecting aquatic environments, is related to agricultural activities. For example, copper sulfate (Bordeaux mixture) is commonly used in large quantities for treatment of grapevines and fruit trees to prevent fungal infestations, resulting in pollution with copper. Overall, fertilizers, fungicides, industrial sludges, treated sewage, and composts or slurry used to fertilize agricultural areas are also likely to be contaminated by metals. The problem is greatly amplified during floods or heavy rains.

In line with the aforementioned facts, it has become necessary to develop new approaches to anticipate such situations, to reduce the number of pollution sources, to treat polluted waters upstream, and to set up innovative treatment processes using sustainable technologies (Ezbakhe 2018).

Herein, we present the latest results from our study on development of a novel approach to these problems: designing filtration columns filled with natural plant-based materials able to retain metal elements that can be used to purify waters polluted with metals. This approach is an innovative "green" solution to prevent any escape of metals in aquatic systems and to avoid the formation of difficult-to-manage industrial sludge. At the same time, it provides innovative ways to combat invasive aquatic plants and to recycle metals for use as industrial catalysts.

\section{Experimental}

All reagents used in this study were of analytical grade: commercial $\mathrm{HNO}_{3}$ and $\mathrm{HCl}$ came from Sigma-Aldrich TraceSELECT ${ }^{\circledR}$ range. All solutions were prepared using double-deionized water (Milli-Q Millipore 18.2M $2 . \mathrm{cm}$ at $21^{\circ} \mathrm{C}$ ). Glassware items were cleaned as follows prior to their use: filling with $\mathrm{HNO}_{3}(20 \%$ w:w) left during $24 \mathrm{~h}$, rinsing three times with double-deionized water, and final rinsing with the solution to be used.

\section{Mineral analyses of effluents}

\section{Analyses by MP-AES}

Digestions were performed by microwave-assisted dissolution using a Multiwave GO microwave system (Anton Paar®). In this procedure, an exact mass $(10 \mathrm{mg})$ was suspended into a Teflon reactor with a mixture of aq. $\mathrm{HCl} 37 \%$ aq. $\mathrm{HNO}_{3} 65 \%$ $(2: 4, v / v, 6 \mathrm{~mL})$. The reactors were heated according to the following program: (rise in temperature from 25 to $165{ }^{\circ} \mathrm{C}$ (20 min), followed by a stage at $\left.165{ }^{\circ} \mathrm{C}(10 \mathrm{~min})\right)$. After cooling for $30 \mathrm{~min}$, the digests were filtered and then diluted to $0.4 \mathrm{mg} \mathrm{L}^{-1}$ in nitric acid $1 \%$.

Mineral compositions were determined by using a microwave plasma-atomic emission spectroscopy (MP-AES) 4200 (Agilent Technologies) equipped with a concentric nebulizer and a double-pass cyclonic spray chamber. The pump speed during analysis was kept at $10 \mathrm{rpm}$ and the sample introduction tube diameter was $0.89 \mathrm{~mm}$. The analytical cycle consisted of 30 -s rinsing with aq. $1 \%$ nitric acid followed by $25 \mathrm{~s}$ of sample uptake (pump speed $40 \mathrm{rpm}$ ) and then $20 \mathrm{~s}$ of equilibration before the reading at preselected integration times (pump speed $10 \mathrm{rpm}$ ). The integration time was set to $3 \mathrm{~s}$ for all elements. Unless otherwise stated, the automatic background correction mode available in the software was used. An Agilent SPS-3 autosampler was used throughout the study. The analyses were repeated three times.

\section{Analyses by ICP-MS}

Inductively coupled plasma-mass spectrometry (ICP-MS) analyses were performed using metal analysis of total dissolved solutes in $2.5 \%$ nitric acid. The dry samples were acidified with $2.5 \%$ nitric acid, stirred for $30 \mathrm{~min}$, and diluted to $0.05 \mathrm{~g} / \mathrm{L}$. Three blanks were recorded for each step (acidification and dilution) on a Thermo scientific X Series II ICP-MS (AETE Platform-Hydrosciences, Montpellier-France).

\section{Fourier transform infrared analysis}

IR spectra were recorded on a Perkin-Elmer Spectrum 100 FTIRß spectrometer in ATR (Attenuated Total Reflexion) mode. The number of scans was 32 , the resolution was 1 point. $\mathrm{cm}^{-1}$. The acquisition was done from 650 to $4000 \mathrm{~cm}^{-1}$. The detector used was a DTGS (Deuterated-TriGlycine Sulfate). The background was done in air.

The calculation of the area of each peak was done by fitting using a combination of Gaussian and Lorentzian functions, in order to better adjust the experimental peaks. This calculation was done after a baseline correction (polynomial function of order 5) and an extraction of the interest zone in $\mathrm{cm}^{-1}$, in order to limit the number of peaks to be fit. This treatment was performed on the Labspec ${ }^{\circledR} 4.18$ software.

\section{Biosorption experiments}

\section{General experimental protocol for biomass preparation}

The biomass was dried in an oven at $80{ }^{\circ} \mathrm{C}$ until constant weight, ground, sifted through a 1.25 mesh sieve, and washed with distilled water $\left(3 \times 100 \mathrm{~mL} \mathrm{~g}^{-1}\right.$ of biomass). The resulted biomass was then again dried overnight in an oven at $80{ }^{\circ} \mathrm{C}$ and used in further biosorptions.

\section{Biosorption in mode batch}

The biomass was submerged in $1 \mathrm{~L}$ of the effluent from Malines (Gard, France) at room temperature. The solution was stirred continuously for $2 \mathrm{~h}$; the mixture was separated 
by filtration. The concentration of remaining metal ions in the effluent was determined by MP -AES analyses.

\section{Biosorption in column mode}

Biosorption in gravity column mode The experiments were conducted in a glass chromatography column (diameter = $1.2 \mathrm{~cm}$ ) with immobilized dried biomass. Deionized water $(10 \mathrm{~mL})$ was added to the column to humidify the biomass; then, $1 \mathrm{~L}$ of the effluent from Malines (Gard, France) was added to the biomass and purified by gravity. After biosorption, the effluent sample was collected and analyzed by MP-AES.

Biosorption using column under normal pressure The experiments were conducted in PuriFlash $\odot$, 430. Biomass ( $2 \mathrm{~g}$ ) was introduced in a flash column $\left(7 \mathrm{~cm} \times 2 \mathrm{~cm}^{2}\right.$, Agela Technologies). The effluent ( $2 \mathrm{~L}$ ) from Malines (Gard, France) was filtered through the biomass with the flow rate of $20 \mathrm{~mL} / \mathrm{min}$. After biosorption, a sample of effluent was collected for mineral analysis by MP-AES analyses.

\section{Results and discussion}

We propose a new system for the depollution of effluents contaminated by metal elements. It is a filter made of plant material (plants were harvested, dried, and ground), insoluble in water, and naturally rich in aromatic or carboxylic groups. Thus, in contrast to phytoremediation (Kumar et al. 2018), our process for depollution of mining waters is based on the use of dead plants. We have discovered that this natural material is able to clean up water contaminated with trace metallic elements (TMEs). The origin of plant material is twofold: (1) terrestrial and aquatic plants native to and abundant in Europe and (2) invasive aquatic plants. Use of the latter could contribute to eradication or control efforts.

The general process is illustrated by a particularly interesting and representative case study of a situation in which management is difficult to control in times of floods and heavy rains. The large mining site of Malines (Saint-Laurent-Le-Minier, Gard, France) was chosen as a model site. A large network of mining galleries is subjected to infiltration by water that percolates on the walls and causes the dissolution of TMEs (especially $\mathrm{Fe}, \mathrm{Zn}, \mathrm{Cd}$, and $\mathrm{Pb}$ ). The effluent composition is related to meteorological conditions, especially occurrence of rains. Monitoring was carried out during rainy days in 2018. The composition of outflow effluents is presented in Table 1.

It is clear that two TMEs, namely Fe and Zn, account for the majority of TMEs present in effluent, regardless of the period of study. The Fe content ranges from 5.5 to $12.7 \mathrm{mg} \mathrm{L}^{-1}$, while the $\mathrm{Zn}$ concentration is between 11.7 and $20.9\left(\mathrm{mg} \mathrm{L}^{-\mathbf{1}}\right)$. Variation in concentrations of both $\mathrm{Fe}$ and $\mathrm{Zn}$ showed identical patterns and reflects the abundance of local rains with a time lag, as showed by the rainfall records (Table 2).

Contents of $\mathrm{Pb}$ and $\mathrm{Cd}$ were low, but the discharge standards are very restrictive $\left(\mathrm{Pb} ; 0.50 \mathrm{mg} \mathrm{L}^{-1}, \mathrm{Cd} ; 0.05 \mathrm{mg} \mathrm{L}^{-1}\right.$, NOR: ATEP9870017A). Additionally, the data presented illustrate the need to use an appropriate analytical method to accurately determine the $\mathrm{Cd}$ and $\mathrm{Pb}$ concentrations in order to comply with the current regulations. Therefore, the February 12th 2018 effluent was analyzed by ICP-MS and also by MPAES, confirming that $\mathrm{Cd}$ and $\mathrm{Pb}$ contents were acceptable (Table 3). The goal of management is therefore to reduce the content of $\mathrm{Fe}$ and $\mathrm{Zn}$ from the effluent to acceptable levels.

\section{Choice of the biomass}

Our process for depolluting mining waters is based on the use of dead plants that are abundant and inexpensive. The plants we chose to test can be classified in two categories:

- plants rich in lignin (category 1): Pine cones and pine bark (Pinus spp.), two green wastes, Fallopia japonica (Japanese knotweed, Polygonaceae), an invasive plant, and wheat straw;

- roots of aquatic plants (category 2): Mentha aquatica (Lamiaceae) is a native, abundant (non-threatened) European plant with a well-developed root system. We also tested three plants considered to be troublesome noxious weeds, in France (Ludwigia peploides, Onagraceae) or elsewhere in the world (Eichhornia crassipes, water hyacinth, Pontederiaceae; and Pistia stratiotes, water lettuce, Araceae).

Table 1 Effluent composition established by MP-AES analysis in 2018

\begin{tabular}{|c|c|c|c|c|c|c|c|c|}
\hline & $\mathrm{Ca}\left(\mathrm{mg} \mathrm{L}^{-1}\right)$ & $\mathrm{Cd}\left(\mathrm{mg} \mathrm{L}^{-1}\right)$ & $\mathrm{Fe}\left(\mathrm{mg} \mathrm{L}^{-1}\right)$ & $\mathrm{K}\left(\mathrm{mg} \mathrm{L}^{-1}\right)$ & $\operatorname{Mg}\left(\mathrm{mg} \mathrm{L}^{-1}\right)$ & $\mathrm{Na}\left(\mathrm{mg} \mathrm{L}^{-1}\right)$ & $\mathrm{Pb}\left(\mathrm{mg} \mathrm{L}^{-1}\right)$ & $\mathrm{Zn}\left(\mathrm{mg} \mathrm{L}^{-1}\right)$ \\
\hline 02 February & 205.4 & $\ll 0.1$ & 5.5 & 7.8 & 90.2 & 4.6 & $\ll 0.5$ & 11.7 \\
\hline 12 February & $\gg 250$ & $\ll 0.1$ & 5.6 & 2.7 & $\gg 73$ & 4.9 & $\ll 0.5$ & 12.3 \\
\hline 21 February & $\gg 250$ & $\ll 0.1$ & 5.6 & 2.9 & 73.2 & 5.7 & $\ll 0.5$ & 12.5 \\
\hline 22 February & $\gg 250$ & $\ll 0.1$ & 5.9 & 2.8 & $\gg 73$ & 5.8 & $\ll 0.5$ & 12.4 \\
\hline 04 March & $\gg 250$ & $\ll 0.1$ & 12.7 & 3.2 & 117.1 & 5.0 & $\ll 0.5$ & 20.9 \\
\hline 04 April & $\gg 250$ & $\ll 0.1$ & 10.9 & 3.1 & 109.6 & 4.5 & $\ll 0.5$ & 19.6 \\
\hline
\end{tabular}


Table 2 Rainfall records January-May 2018, Saint-Laurent-LeMinier, Gard, France

\begin{tabular}{ll}
\hline Months (2018) & Rainfall totals (mm) \\
\hline January & 412 \\
February & 185 \\
March & 324 \\
April & 315 \\
May & 343 \\
\hline
\end{tabular}

Additionally, the biomass used is insoluble in water, its structure being based on carbon-containing aromatic compounds and many carboxylate groups naturally present in the material of plant origin. The presence of aromatic compounds and carboxylic acids was unambiguously confirmed by Infrared Spectroscopy (IR) analysis using Fourier Transform Infrared Spectrometry (FT-IR). The principle of the analysis was based on comparison of the absorption intensities of bands corresponding to the aromatic ring and bands characteristic of the carboxylate unit $\mathrm{C}=\mathrm{O}$ bond.

On the IR spectra, aromatic compounds show absorptions in the region around $1600 \mathrm{~cm}^{-1}$ due to carbon-carbon stretching vibrations in the aromatic ring. In turn, carboxylate units are characterized by an intense band in the region 1650$1550 \mathrm{~cm}^{-1}$ corresponding the carbonyl stretch $\mathrm{C}=\mathrm{O}$ from the $\mathrm{COO}-$ group and the $\mathrm{O}-\mathrm{H}$ band in the region around $1400 \mathrm{~cm}^{-1}$. After a mathematical fitting, we determined the area ratio of the $\mathrm{C}=\mathrm{O}$ bond vibration band and the aromatic ring vibration bands (see Supporting information). The data obtained are presented in Table 4.

From the results obtained, it is clear that the lignin-rich materials (category 1) have the area ratio between the $\mathrm{C}=\mathrm{O}$ bond and aromatic ring bond bands lower than 1 . In turn, materials based on roots from aquatic plants are rich in carboxylate function (category 2), which results in an area ratio in the range of 1.15-2.02. This fact makes the latter category potentially more suitable for the biosorption of TMEs, owing to a stronger affinity for metals based on the formation of metal carboxylate salts.

\section{Biosorption experiments}

After washing with water, drying, and grinding, the plantbased materials had the structure of fine powder with the particle size between 0.5 and $1.25 \mathrm{~mm}$ and was stored at $80^{\circ} \mathrm{C}$. The biosorption processes were carried out in batch or in columns. The effectiveness of the biosorption was evaluated by analysis of the mining effluent before and after passing through the biomass. The analysis of mineral composition was performed using MP-AES.

\section{Biosorption in batch mode}

Varying quantities of the plant-based powder were added to $1 \mathrm{~L}$ of mining effluent. The mixture was stirred for $2 \mathrm{~h}$ and then filtered. The effluent after biosorption was directly analyzed. The results obtained are shown in Table 5.

Results of the biosorption tests clearly showed that all the plant-based materials were able to almost completely remove Fe from the tested mining effluent (Table 5). This is consistent with the known high affinity of iron for phenol groups such as lignin-based materials (category 1, Merdy et al. 2003) and phenolic acids (category 2). On the other hand, the ability of the materials to remove $\mathrm{Zn}$ was more variable. For example, using $3 \mathrm{~g}$ of biomass from roots of Eichhornia crassipes, the mining effluent containing $\mathrm{Zn}$ at $11.7 \mathrm{mg} \mathrm{L}^{-1}$ could be purified to reach a $\mathrm{Zn}$ concentration of $1.9 \mathrm{mg} \mathrm{L}^{-1}$ after biosorption was completed (Table 5). This is particularly interesting because this $\mathrm{Zn}$ concentration is below the allowed standards $\left(\left(2 \mathrm{mg} \mathrm{L}^{-1}\right)\right.$, NOR: ATEP9870017A 2019). Importantly, no desorption phenomenon was observed. In turn, the plant-based materials derived from pine cones were in general effective, but did not allow reaching acceptable concentrations of $\mathrm{Zn}$ after biosorption. For example, with $5 \mathrm{~g} \mathrm{~L}^{-1}$ of biomass, $\mathrm{Zn}$ concentration in effluent initially containing $11.7 \mathrm{mg} \mathrm{L}^{-1}$ could be reduced to $3.2 \mathrm{mg} \mathrm{L}^{-1}$. Therefore, the interest of using pine cone-based material for biosorption purposes is limited to immediate and very effective retention of Fe (Table 5). The best results were obtained with the use of biomass from Mentha aquatica (Table 5). With only $1 \mathrm{~g} \mathrm{~L}^{-1}$ of this material, $\mathrm{Zn}$ concentration of effluent initially containing $12.4 \mathrm{mg} \mathrm{L}^{-1}$ could be reduced to $2.4 \mathrm{mg} \mathrm{L}^{-1}$ of $\mathrm{Zn}$. With these encouraging results in hand, we began testing biosorption processes using column mode, an approach more suitable for automated processing of purification.

\section{Biosorption in column mode}

Biosorption in column mode was carried out using two approaches: simple gravity column biosorption or column biosorption under pressure using a cartridge filled with suitable plant-based biomass.
Table 3 Results of ICP-MS and MP-AES analyses of effluent for February 12th, 2018

\begin{tabular}{lllllll}
\hline ANALYSIS & $\mathrm{Ca}\left(\mathrm{mg} \mathrm{L}^{-1}\right)$ & $\mathrm{Cd}\left(\mathrm{mg} \mathrm{L}^{-1}\right)$ & $\mathrm{Fe}\left(\mathrm{mg} \mathrm{L}^{-1}\right)$ & $\mathrm{Mg}\left(\mathrm{mg} \mathrm{L}^{-1}\right)$ & $\mathrm{Pb}\left(\mathrm{mg} \mathrm{L}^{-1}\right)$ & $\mathrm{Zn}\left(\mathrm{mg} \mathrm{L}^{-1}\right)$ \\
\hline MP-AES & $288.6^{*}$ & $\ll 0.1$ & 5.6 & $103.2 *$ & $\ll 0.5$ & 12.3 \\
ICP-MS & 288.01 & 0.010 & 6.94 & 92.37 & $\ll 0.5$ & 11.86 \\
\hline
\end{tabular}

*Values obtained after dilution 
Table 4 FT-IR analysis of the plant-based materials used

\begin{tabular}{|c|c|c|c|}
\hline Biomaterials & Area of the $\mathrm{C}=\mathrm{O}$ band of $\mathrm{COO}-\left(\mathrm{cm}^{-1}\right)$ & $\begin{array}{l}\text { Area of the band of } \\
\text { aromatic cycle }\left(\mathrm{cm}^{-1}\right)\end{array}$ & $\begin{array}{l}\text { Ratio of areas } \\
\mathrm{C}=\mathrm{O} / \mathrm{Ar}\end{array}$ \\
\hline \multicolumn{4}{|l|}{ Category 2 plant-based materials } \\
\hline Roost of Eichhornia crassipes & $\begin{array}{l}0.35+0.48+0.69+0.26(1657+1653+ \\
\left.\quad 1650+1631 \mathrm{~cm}^{-1}\right)\end{array}$ & $0.88\left(1607 \mathrm{~cm}^{-1}\right)$ & 2.02 \\
\hline Roots of Pistia stratiotes & $1.73\left(1640 \mathrm{~cm}^{-1}\right)$ & $1.11\left(1572 \mathrm{~cm}^{-1}\right)$ & 1.56 \\
\hline Roots of Mentha aquatica & $1.34\left(1638 \mathrm{~cm}^{-1}\right)$ & $0.81\left(1582 \mathrm{~cm}^{-1}\right)$ & 1.65 \\
\hline Roots of Ludwigia peploides & $0.70\left(1654 \mathrm{~cm}^{-1}\right)$ & $0.61\left(1602 \mathrm{~cm}^{-1}\right)$ & 1.15 \\
\hline \multicolumn{4}{|l|}{ Category 1 plant-based materials } \\
\hline Roots of Fallopia japonica & $0.13+0.24\left(1670+1633 \mathrm{~cm}^{-1}\right)$ & $0.51\left(1597 \mathrm{~cm}^{-1}\right)$ & 0.72 \\
\hline Pine bark & $0.14+0.94\left(1667+1630 \mathrm{~cm}^{-1}\right)$ & $1.76\left(1603 \mathrm{~cm}^{-1}\right)$ & 0.63 \\
\hline Pine cone & $0.19\left(1644 \mathrm{~cm}^{-1}\right)$ & $0.32\left(1602 \mathrm{~cm}^{-1}\right)$ & 0.53 \\
\hline Wheat straw & $0.19\left(1679-1628 \mathrm{~cm}^{-1}\right)$ & $0.20\left(1604-1593 \mathrm{~cm}^{-1}\right)$ & 0.95 \\
\hline
\end{tabular}

The first experiments of biosorption of mining effluent were carried out with the use of columns filled with plantbased biomass in gravity mode (Table 6).

In gravity column mode, the good performance of biomass issued from Eichhornia crassipes in biosorption of $\mathrm{Fe}$ and $\mathrm{Zn}$ from mining effluents was confirmed, but not improved (compared with batch mode). Interestingly, the mixture of biomass from pine cones and Eichhornia crassipes, with only $0.5 \mathrm{~g} \mathrm{~L}^{-1}$ of each biomass, enabled good purification of mining effluent and reduced the initial $\mathrm{Zn}$ content from 12.4 to $5.1 \mathrm{mg} \mathrm{L}^{-1}$ after biosorption (Table 6). These results remain in agreement with the structural properties of the plant-based materials as shown by FT-IR analysis. The biomass from pine cones, rich in lignin and low in carboxylate groups, was ideal for biosorption of Fe, whereas the biomass from Eichhornia crassipes, rich in carboxylate groups, was especially suited for biosorption of $\mathrm{Zn}$.

During the biosorption tests using the column mode, we observed precipitation of $\mathrm{Fe}$ (III), at $\mathrm{pH}=7$, during prolonged storage of the contaminated effluent and also during column elution. This fact was responsible for column clogging. In order to circumvent this problem, biosorption tests were studied with a double filter. Plant-based biomass rich in lignin was used to build a pre-filter capable of rapid and effective biosorption of Fe (III). The tests were carried out in gravity column mode. Biomass from roots of selected aquatic plants, rich in carboxylate motifs and effective for retaining $\mathrm{Zn}, \mathrm{Cd}$, and $\mathrm{Pb}$, was used as a main filter. New biosorption tests were carried out with this dual system composed of pre-filter and main filter (Table 7).

Table 5 Biosorption of mining effluent using plant-based sorbents in batch mode

\begin{tabular}{|c|c|c|c|c|c|c|c|c|c|}
\hline Label & & $\mathrm{Ca}\left(\mathrm{mg} \mathrm{L}^{-1}\right)$ & $\mathrm{Cd}\left(\mathrm{mg} \mathrm{L}^{-1}\right)$ & $\mathrm{Fe}\left(\mathrm{mg} \mathrm{L}^{-1}\right)$ & $\mathrm{K}\left(\mathrm{mg} \mathrm{L}^{-1}\right)$ & $\operatorname{Mg}\left(\mathrm{mg} \mathrm{L}^{-1}\right)$ & $\mathrm{Na}\left(\mathrm{mg} \mathrm{L}^{-1}\right)$ & $\mathrm{Pb}\left(\mathrm{mg} \mathrm{L}^{-1}\right)$ & $\mathrm{Zn}\left(\mathrm{mg} \mathrm{L}^{-1}\right)$ \\
\hline $\begin{array}{l}\text { Initial concentration } \\
\text { of mining effluent }\end{array}$ & & 205.4 & 0.0 & 5.5 & 7.8 & 90.2 & 4.6 & $\ll 0.5^{*}$ & 11.7 \\
\hline $\begin{array}{l}\text { Eichhornia crassipes } \\
\text { roots }\end{array}$ & $1 \mathrm{~g} \mathrm{~L}^{-1}$ & $\gg 250$ & $\ll 0.1 *$ & 0.2 & 16.9 & $\gg 73$ & 19.2 & $\ll 0.5^{*}$ & 3.6 \\
\hline $\begin{array}{l}\text { Eichhornia crassipes } \\
\text { roots }\end{array}$ & $3 \mathrm{~g} \mathrm{~L}^{-1}$ & $\gg 250$ & $\ll 0.1 *$ & 0.3 & 29.8 & $\gg 73$ & 28.8 & $\ll 0.5^{*}$ & 0.9 \\
\hline $\begin{array}{l}\text { Eichhornia crassipes } \\
\text { roots }\end{array}$ & $5 \mathrm{~g} \mathrm{~L}^{-1}$ & $\gg 250$ & $\ll 0.1 *$ & 0.3 & $\gg 60$ & $\gg 73$ & 45.5 & $\ll 0.5^{*}$ & 0.6 \\
\hline Pine cones & $1 \mathrm{~g} \mathrm{~L}^{-1}$ & $\gg 250$ & $\ll 0.1 *$ & $\ll 0.1 *$ & 4.2 & $\gg 73$ & 4.8 & $\ll 0.5^{*}$ & 5.5 \\
\hline Pine cones & $5 \mathrm{~g} \mathrm{~L}^{-1}$ & $\gg 250$ & $\ll 0.1^{*}$ & $\ll 0.1^{*}$ & 10 & $\gg 73$ & 6.2 & $\ll 0.5$ & 3.1 \\
\hline $\begin{array}{l}\text { Initial concentration } \\
\text { of mining effluents }\end{array}$ & & $\gg 250$ & $\ll 0.1 *$ & 5.6 & 2.7 & $\gg 73$ & 4.9 & $\ll 0.5^{*}$ & 12.3 \\
\hline Pine cones & $3 \mathrm{~g} \mathrm{~L}^{-1}$ & $\gg 250$ & $\ll 0.1 *$ & $\ll 0.1 *$ & 8.6 & $\gg 73$ & 7.6 & $\ll 0.5^{*}$ & 3.7 \\
\hline $\begin{array}{l}\text { Initial concentration } \\
\text { of mining effluent }\end{array}$ & & $\gg 250$ & $\ll 0.1 *$ & 5.9 & 2.8 & $\gg 73$ & 5.8 & $\ll 0.5^{*}$ & 12.4 \\
\hline Mentha aquatica roots & $1 \mathrm{~g} \mathrm{~L}^{-1}$ & $\gg 250$ & $\ll 0.1 *$ & 0.2 & 5.4 & $\gg 73$ & 9.5 & $\ll 0.5^{*}$ & 2.4 \\
\hline Mentha aquatica roots & $3 \mathrm{~g} \mathrm{~L}^{-1}$ & $\gg 250$ & $\ll 0.1 *$ & 0.2 & 11.3 & $\gg 73$ & 20.2 & $\ll 0.5^{*}$ & 1.0 \\
\hline
\end{tabular}

Italicized values correspond to the best results obtained meaning the lowest concentration of TMEs after biosorption

*Values below the MP-AES detection limit 
The results presented in Table 7 clearly show that the use of biomass from pine cones, wheat straw, sawdust, pine bark, or Fallopia japonica roots as a pre-filter in biosorption of metalcontaminated mining effluents, results in significant decreases in Fe content. The resulting effluent can then be passed through the primary filter composed of biomass from roots of aquatic species: Eichhornia crassipes, Mentha aquatica, Ludwigia peploides, or Pistia stratiotes. Due to its structural characteristics, mainly abundance of carboxylate groups, such biomass is especially suited for biosorption of $\mathrm{Zn}$ (Table 7).

Importantly, it is also possible to prepare the pre-filter and filter systems exclusively from biomass from aquatic species, e.g., to prepare the pre-filter using biomass from Fallopia japonica and then use biomass from Eichhornia crassipes or Ludwigia peploides as the main filter, in order to obtain strong reduction in both $\mathrm{Fe}$ and $\mathrm{Zn}$ contents of mining effluents (Table 7). Since these plants are considered to be troublesome noxious weeds, the biomass from control or eradication of these species can find an eco-friendly application in the purification of metal-contaminated mining effluents.

The results presented in Table 7 demonstrate the utility of plant-based biomass in the purification of metal-contaminated mining effluents. This goal can be achieved through a careful combination of biomass from plants, both terrestrial and aquatic, that occur abundantly in Europe, some of which are native and others invasive introduced species.

In Europe, there are more than 12,000 human-introduced invasive plant species (Vila et al. 2009). Among these species, Ludwigia peploides and Pistia stratiotes are currently considered to be invasive in numerous rivers of France, Germany, and Italy. For example, $360 \mathrm{~T}$ of $L$. peploides were extracted in 5 days from Briere marshlands (France) in 2015 (Blottiere 2017). Many studies have shown that control of invasive plants is a more realistic goal than their eradication (Issanchou 2012). The spread of these plants threatens ecosystems, with negative ecological, economic, or health consequences. The management of invasive plants requires persistent and huge efforts to control the worst invader, Ludwigia peploides (Lambert et al. 2010). The use of $L$. peploides as biosorbent materials could turn invasive plants into a resource to help finance or offset the costs of their control. Using plants in such a filtering system could help to limit their populations, whose rate of proliferation is still sufficiently rapid that they would be able to persist at levels high enough to continue supplying material.

Furthermore, the biosorption process is not dependent on the use of invasive species. The performances of Mentha aquatica were particularly remarkable. It is a perennial plant but not intrusive, and is widely distributed around the world. It is a facultative hydrophyte. It is easily propagated by seeds or transplanting and can be grown hydroponically, rapidly producing large amounts of biomass (Zuryak et al. 2002).

Plant waste produced by biosorption could be recovered using an innovative concept of ecological recycling. This opportunity is based on the pioneering approach of our group, which addresses the direct use of metals derived from contaminated plant waste as supported "Lewis acid" catalysts, oxidizing and reducing reagents and coupling agents in organic chemistry for the preparation of biomolecules (Clavé et al. 2017; Deyris and Grison 2018; Escande et al. 2015a, b, c, d, 2017; Grison 2015). The biosorption technology based on the use of modified vegetable wastes to bioconcentrate $\mathrm{Fe}$ and $\mathrm{Zn}$ to access and to design next-generation catalytic materials is promising: the two metallic elements present very interesting Lewis Acidity. According to advanced theories (HSAB, Corma and Gutmann-Denmark) for anticipating catalytic activity, synergistic effects between $\mathrm{Fe}, \mathrm{Zn}$, and physiological elements $(\mathrm{Ca}, \mathrm{Mg}, \mathrm{Na}, \mathrm{K})$ can be anticipated (Deyris et al. 2018, Deyris and Grison 2018; Escande et al. 2013, 2014a, b, 2015a, b, c, d; Losfeld et al. 2012a, b, Grison et al. 2015a, b, Thillier et al. 2013). This study is ongoing.

Finally, the world's exploitable $\mathrm{Zn}$ resources could be exhausted in 17 years; therefore, development of recycling processes is crucial (Pitron 2018). Given the flow of contaminated water to be purified in the tested site $\left(15 \mathrm{~m}^{3} \mathrm{~h}^{-1}\right)$, an average concentration of $\mathrm{Zn}$ over 1 year close to $12.5 \mathrm{mg} \mathrm{L}^{-1} \mathrm{Zn}$, and the annual duration of rains ( 7 months/12), it is possible to recycle $945 \mathrm{~kg}$ of $\mathrm{Zn}$ per year by reprocessing this single effluent. Considering that $1 \mathrm{~g}$ of $L$. peploides is required to purify $1 \mathrm{~L}$ of effluent (Table 7), 75.6 T of L. peploides will be needed for 1 year. Supplying this quantity is very manageable

Table 6 MP-AES analysis of effluent after biosorption using column in gravity mode

\begin{tabular}{|c|c|c|c|c|c|c|c|c|c|}
\hline \multicolumn{2}{|l|}{ Label } & $\begin{array}{l}\mathrm{Ca} \\
\left(\mathrm{mg} \mathrm{L}^{-1}\right)\end{array}$ & $\begin{array}{l}\mathrm{Cd} \\
\left(\mathrm{mg} \mathrm{L}^{-1}\right)\end{array}$ & $\begin{array}{l}\mathrm{Fe} \\
\left(\mathrm{mg} \mathrm{L}^{-1}\right)\end{array}$ & $\begin{array}{l}\mathrm{K} \\
\left(\mathrm{mg} \mathrm{L}^{-1}\right)\end{array}$ & $\begin{array}{l}\mathrm{Mg} \\
\left(\mathrm{mg} \mathrm{L}^{-1}\right)\end{array}$ & $\begin{array}{l}\mathrm{Na} \\
\left(\mathrm{mg} \mathrm{L}^{-1}\right)\end{array}$ & $\begin{array}{l}\mathrm{Pb} \\
\left(\mathrm{mg} \mathrm{L}^{-1}\right)\end{array}$ & $\begin{array}{l}\mathrm{Zn} \\
\left(\mathrm{mg} \mathrm{L}^{-1}\right)\end{array}$ \\
\hline \multicolumn{2}{|c|}{ Initial concentration of mining effluent } & $\gg 250$ & $\ll 0.1$ & 5.6 & 2.9 & 95.9 & 4.9 & $\ll 0.5$ & 12.4 \\
\hline Pine cones & $1 \mathrm{~g} \mathrm{~L}^{-1}$ & $\gg 250$ & $\ll 0.1$ & $\ll 0.1$ & 3.4 & $\gg 73$ & 4.7 & $\ll 0.5$ & 9.4 \\
\hline Pine cones & $5 \mathrm{~g} \mathrm{~L}^{-1}$ & $\gg 250$ & $\ll 0.1$ & $\ll 0.1$ & 6.1 & $\gg 73$ & 6.6 & $\ll 0.5$ & 5.2 \\
\hline $\begin{array}{l}\text { Pine cones }+ \\
\quad \text { Eichhornia crassipes }\end{array}$ & $0,5 \mathrm{~g} \mathrm{~L}^{-1}+0,5 \mathrm{~g} \mathrm{~L}^{-1}$ & $\gg 250$ & $\ll 0.1$ & 0.2 & 8.4 & $\gg 73$ & 10.3 & $\ll 0.5$ & 5.1 \\
\hline Eichhornia crassipes & $3 \mathrm{~g} \mathrm{~L}^{-1}$ & $\gg 250$ & $\ll 0.1$ & $\ll 0.1$ & 3.1 & $\gg 73$ & 5.2 & $\ll 0.5$ & 1.1 \\
\hline
\end{tabular}

Italicized values correspond to the best results obtained meaning the lowest concentration of TMEs after biosorption 
Table 7 Results of tests of biosorption of mining effluents in column mode using a double filter, determined by MP-AES

\begin{tabular}{|c|c|c|c|c|c|c|c|c|c|}
\hline Label & & $\begin{array}{l}\mathrm{Ca} \\
\left(\mathrm{mg} \mathrm{L}^{-1}\right)\end{array}$ & $\begin{array}{l}\mathrm{Cd} \\
\left(\mathrm{mg} \mathrm{L}^{-1}\right)\end{array}$ & $\begin{array}{l}\mathrm{Fe} \\
\left(\mathrm{mg} \mathrm{L}^{-1}\right)\end{array}$ & $\begin{array}{l}\mathrm{K} \\
\left(\mathrm{mg} \mathrm{L}^{-1}\right)\end{array}$ & $\begin{array}{l}\mathrm{Mg} \\
\left(\mathrm{mg} \mathrm{L}^{-1}\right)\end{array}$ & $\begin{array}{l}\mathrm{Na} \\
\left(\mathrm{mg} \mathrm{L}^{-1}\right)\end{array}$ & $\begin{array}{l}\mathrm{Pb} \\
\left(\mathrm{mg} \mathrm{L}^{-1}\right)\end{array}$ & $\begin{array}{l}\mathrm{Zn} \\
\left(\mathrm{mg} \mathrm{L}^{-1}\right)\end{array}$ \\
\hline Initial composition of effluent & & $\gg 250$ & $\ll 0.1$ & 7.1 & 3.6 & $\gg 73$ & 6.5 & $\ll 0.5$ & 14.9 \\
\hline Pre-filter: pine cones & $1 \mathrm{~g} \mathrm{~L}^{-1}$ & $\gg 250$ & $\ll 0.1$ & $\ll 0.1$ & 3.3 & $\gg 73$ & 5.7 & $\ll 0.5$ & 9.8 \\
\hline Filter: Eichhornia crassipes & $3 \mathrm{~g} \mathrm{~L}^{-1}$ & $\gg 250$ & $\ll 0.1$ & $\ll 0.1$ & 3.9 & $\gg 73$ & 5.30 & $\ll 0.5$ & 1.5 \\
\hline Initial composition of effluent & & $\gg 250$ & $\ll 0.1$ & 8.1 & 2.8 & 99.2 & 2.6 & $\ll 0.5$ & 16.9 \\
\hline Pre-filter: wheat straw & $1 \mathrm{~g} \mathrm{~L}^{-1}$ & $\gg 250$ & $\ll 0.1$ & 7 & 3.4 & 111.3 & 4.7 & $\ll 0.5$ & 16.2 \\
\hline Filter: wheat straw & $3 \mathrm{~g} \mathrm{~L}^{-1}$ & $\gg 250$ & $\ll 0.1$ & $\ll 0.1$ & 3.4 & 110.4 & 8.1 & $\ll 0.5$ & 12.8 \\
\hline Pre-filter: Mentha aquatica & $1 \mathrm{~g} \mathrm{~L}^{-1}$ & $\gg 250$ & $\ll 0.1$ & 3.1 & 5.5 & 112.8 & 6.0 & $\ll 0.5$ & 15.6 \\
\hline Filter: Mentha aquatica & $3 \mathrm{~g} \mathrm{~L}^{-1}$ & $\gg 250$ & $\ll 0.1$ & $\ll 0.1$ & 5.5 & 106.3 & 6.4 & $\ll 0.5$ & 0.7 \\
\hline Pre-filter: Ludwigia peploides & $1 \mathrm{~g} \mathrm{~L}^{-1}$ & $\gg 250$ & $\ll 0.1$ & 2.3 & 28.2 & 113.7 & 7.1 & $\ll 0.5$ & 15.9 \\
\hline Filter: Ludwigia peploides & $3 \mathrm{~g} \mathrm{~L}^{-1}$ & $\gg 250$ & $\ll 0.1$ & $\ll 0.1$ & 28.9 & 108.8 & 7.5 & $\ll 0.5$ & 1.7 \\
\hline Pre-filter: Sawdust of pine & $1 \mathrm{~g} \mathrm{~L}^{-1}$ & $\gg 250$ & $\ll 0.1$ & 5.5 & 4.1 & 112.2 & 3.3 & $\ll 0.5$ & 16.9 \\
\hline Filter: Sawdust of pine & $3 \mathrm{~g} \mathrm{~L}^{-1}$ & $\gg 250$ & $\ll 0.1$ & $\ll 0.1$ & 6.41 & 109.2 & 3.4 & $\ll 0.5$ & 14.3 \\
\hline Initial composition of effluent & & $\gg 250$ & $\ll 0.1$ & 7.3 & 3.4 & 113.2 & 3.2 & $\ll 0.5$ & 16.8 \\
\hline Pre-filter: Fallopia japonica & $1 \mathrm{~g} \mathrm{~L}^{-1}$ & $\gg 250$ & $\ll 0.1$ & $\ll 0.1$ & 3.6 & 113.5 & 3.3 & $\ll 0.5$ & 13.9 \\
\hline Filter: Fallopia japonica & $3 \mathrm{~g} \mathrm{~L}^{-1}$ & $\gg 250$ & $\ll 0.1$ & $\ll 0.1$ & 3.8 & 112.1 & 3.5 & $\ll 0.5$ & 6.1 \\
\hline Pre-filter: pine bark & $1 \mathrm{~g} \mathrm{~L}^{-1}$ & $\gg 250$ & $\ll 0.1$ & $\ll 0.1$ & 3.5 & 110 & 3.7 & $\ll 0.5$ & 10.4 \\
\hline Filter: pine bark & $3 \mathrm{~g} \mathrm{~L}^{-1}$ & $\gg 250$ & $\ll 0.1$ & $\ll 0.1$ & 4.9 & $\gg 73$ & 5.3 & $\ll 0.5$ & 6.00 \\
\hline Initial composition of effluent & & $\gg 250$ & $\ll 0.1$ & 7.4 & 2.9 & 113.1 & 2.8 & $\ll 0.5$ & 14.6 \\
\hline Pre-filter: Ludwigia peploides & $1 \mathrm{~g} \mathrm{~L}^{-1}$ & $\gg 250$ & $\ll 0.1$ & $\ll 0.1$ & 3.4 & 103.6 & 4.0 & $\ll 0.5$ & 5.4 \\
\hline Filter: Ludwigia peploides & $1 \mathrm{~g} / \mathrm{L}$ & $\gg 250$ & $\ll 0.1$ & $\ll 0.1$ & 5.77 & 106.2 & 5.02 & $\ll 0.5$ & 1.89 \\
\hline Filter: Pistia stratiotes & $1 \mathrm{~g} \mathrm{~L}^{-1}$ & $\gg 250$ & $\ll 0.1$ & $\ll 0.1$ & 3.5 & 104.6 & 4.4 & $\ll 0.5$ & 3.7 \\
\hline Initial composition of effluent & & 271.0 & $\ll 0.1$ & 7.91 & 2.9 & 107.3 & 2.7 & $\ll 0.5$ & 12.1 \\
\hline Pre-filter: pine cones & $1 \mathrm{~g} \mathrm{~L}^{-1}$ & 384.2 & $\ll 0.1$ & $\ll 0.1$ & 3.1 & 109.8 & 3.6 & $\ll 0.5$ & 8.5 \\
\hline Filter: Ludwigia peploides & $1 \mathrm{~g} \mathrm{~L}^{-1}$ & $\gg 250$ & $\ll 0.1$ & $\ll 0.1$ & 4.7 & 129.0 & 2.9 & $\ll 0.5$ & 2.4 \\
\hline
\end{tabular}

Italicized values correspond to the best results obtained meaning the lowest concentration of TMEs after biosorption

considering annual harvests. A scale-up for an industrial development is being studied. It would be interesting to compare the performance of our system with the pilot unit (PU) installed in Greece, which is based on a different system. It consists of a $\mathrm{pH}$ regulation and oxidation stage, followed by filtration to a catalytic multimedia filter, activated carbon filter, and a reverse osmosis (RO) unit (Yfantis et al. 2018).

\section{Conclusions}

We have developed an effective method for purification of metal-contaminated mining effluents. Our results constitute the first demonstrative example of such purification, conducted on an industrial effluent corresponding to a real-case scenario of contaminated, complex polymetallic effluents. The method developed is based on the ability of plant-based biomass to purify the contaminated effluent. The key feature of the proposed system is the use of a pre-filter, preferably composed of woodyplant biomass, in order to remove $\mathrm{Fe}(\mathrm{III})$ and prevent it from clogging the system. Subsequently, the main filter, from biomass rich in carboxylates, should be applied in order to remove $\mathrm{Zn}$.
The interest of the plant-based filter system we present is threefold:

- The system represents an interesting solution to an important environmental problem, the decontamination of metalpolluted water, and prevention of dispersal of metals into the environment. It also eliminates the formation of contaminated sludge whose management is difficult;

- The metal-rich powder is not a waste, because it can be recovered as catalyst;

- Finally, the methodology developed relies on the use of biomass from plants abundant in Europe, some of them are considered to be noxious weeds. Our methodology is thus a sustainable way of managing the biomass gained from efforts to control or eradicate these plants.

Funding information The authors gratefully acknowledge financial support from the Centre National de la Recherche Scientifique (CNRS), FEDER- UNION EUROPEENNE- Région Occitanie, Klorane Botanical Foundation (KBF), Suez Foundation, Compagnie Nationale du Rhône (CNR), and Alain Canales (Syndicat Mixte Ganges le Vigan) for the crops of Fallopia japonica. 


\section{References}

Blottiere D (2017) http://www.gt-ibma.eu/wp-content/uploads/2018/07/ 16072018_comprendre-pour-agir_eee_experiences-de-gestion vol3 vf.pdf, 76

Cisneros J, Oki T, Arnell NW, Benito G, Cogley JG, Döll P, Jiang T, Mwakalila SS (2014) Freshwater resources. In: Climate change 2014: impacts, adaptation and vulnerability. Part A: Global and Sectoral Aspects. Contribution of Working Group II to the Fifth Assessment Report of the Intergovernmental Panel on Climate Change, Chapter 3 (Freshwater Resources), 229-269

Clavé G, Pelissier F, Campadelli S, Grison C (2017) Ecocatalyzed Suzuki-Miyaura cross coupling of heteroaryl compounds. Green Chem 19:4093-4103

Crimmins A, Balbus J, Gamble JL, Beard CB, Bell JE, Dodgen D, Eisen RJ. Fann N, Hawkins MD, Herring SC, Jantarasami L, Mills DM, Saha S, Sarofim MC, Trtanj J, Ziska L (2016) The impacts of climate change on human health in the United States: a scientific assessment. , Eds. U.S. Global Change Research Program, Washington, DC, 312

Decision No 2455/2001/EC of the European Parliament and of the Council of 20 November 2001 establishing the list of priority substances in the field of water policy and amending Directive 2000/60/ EC Official Journal L 331, 2001, 0001-0005

Deyris PA, Grison C (2018) Nature, ecology and chemistry: an unusual combination for a new green catalysis, ecocatalysis. Curr Opin Green Sustain Chem 10:6-10

Deyris PA, Petit E, Legrand YM, Diliberto S, Boulanger C, Bert V, Grison C (2018) Biosourced polymetallic catalysis: a surprising and efficient means to promote the Knoevenagel condensation. Front Chem 6:48. https://doi.org/10.3389/fchem.2018.00048

Escande V, Garoux L, Grison CM, Thillier Y, Debart F, Vasseur JJ, Boulanger C, Grison C (2013) Ecological catalysis and phytoextraction: symbiosis for future. Appl Catal B 146:1-298

Escande V, Petit E, Olszewski T, Grison C (2014a) Zn biosourced catalysts: an efficient way for the synthesis of under-exploited platform molecules from carbohydrates. ChemSusChem 7(7):1915-1923

Escande V, Olszewski T, Grison C (2014b) Preparation of ecological catalysts derived from $\mathrm{Zn}$ hyperaccumulating plants and their catalytic activity in Diels-Alder reaction. Comptes-Rendus de l'Académie des Sciences, article sur invitation 17:731-737

Escande V, Olszewski T, Grison C (2015a) From biodiversity to catalytic diversity: how to control the reaction mechanism by the nature of metallophytes. Environ Sci Pollut Res 22:5653-5666

Escande V, Velati A, Grison C (2015b) Ecocatalysis for 2H-chromenes synthesis: an integrated approach for phytomanagement of polluted ecosystems. Environ Sci Pollut Res 22:5677-5685

Escande V, Velati A, Garel C, Renard BL, Petit E, Grison C, Phytoextracted mining wastes for Ecocatalysis $(2015 \mathrm{c})$ Eco-Mn®, an efficient and eco-friendly plant-based catalyst for reductive amination of ketones. Green Chem 17:2188-2199

Escande V, Petit E, Garoux L, Boulanger C, Grison C (2015d) Switchable alkene epoxidation/oxidative cleavage with $\mathrm{H}_{2} \mathrm{O}_{2}-\mathrm{NaHCO}_{3}$ : efficient heterogeneous catalysis derived from biosourced eco-Mn. ACS Sustain Chem Eng 3(11):2704-2715

Escande V, Poullain C, Clavé G, Petit E, Masquelez N, Hesemann P, Grison C (2017) Alternative green and ecological input for transfer hydrogenation using $\mathrm{EcoNi}(0)$ catalyst in isopropanol. Applied Catalysis B. 210:495-503

Ezbakhe F (2018) Addressing Water Pollution as a means to achieving the sustainable development goals. J Water Pollut Control 2018 $1(1): 6$
Grison C (2015) Combining phytoextraction and ecocatalysis: an environmental, ecological, ethic and economic opportunity. Environ Sci Pollut Res 22:5589-5698

Grison CM, Mazel M, Sellini A, Escande V, Biton J, Grison C (2015a) The leguminous species Anthyllis vulneraria as a $\mathrm{Zn}$ hyperaccumulator and eco-Zn catalyst resources. Environ Sci Pollut Res 22:5667-5676

Grison CM, Escande V, Velati A, Grison C (2015b) Metallophytes for organic synthesis: towards new greener selective protection $/$ deprotection procedures. Environ Sci Pollut Res 22:5686-5698

Issanchou A (2012) http://www.gt-ibma.eu/wp-content/uploads/2013/01/ Issanchou-Memoire-Economie-Jussie.pdf

Kumar K, Yadava K, Guptaa N, Kumarb A, Reecec LM, Singhd N, Rezaniae S, Khanf SA (2018) Mechanistic understanding and holistic approach of phytoremediation: a review on application and future prospects. Ecol Eng 120:274-298

Lambert E, Dutartre A, Coudreuse J, Haury J (2010) Relationships between the biomass production of invasive Ludwigia species and physical properties of habitats in France. Hydrobiologia 656:173-186

Losfeld G, De Vidal L, Blache P, Escande V, L'huillier L, Grison C (2012a) Design and performance of green supported Lewis acid catalysts derived from biomass for Friedel-crafts alkylation and acylation. Catal Today 189(Iss 1):111-116

Losfeld G, Vidal De La Blache P, Escande V, Grison C (2012b) Zinc hyperaccumulating plants as renewable resources for the chlorination of alcohols, Green. Chem Lett Rev:1-6

Luoma SN, Rainbow PS (2008) Metal contamination in aquatic environments: science and lateral management. Cambridge University Press, S. N.Luoma; P.S. Rainbow

Merdy P, Guillon E, Frapart YM, Aplincourt M (2003) Iron and manganese surface complex formation with extracted lignin. New J Chem 27:577-582

NOR: ATEP9870017A - consolidated version of 14 February 2019, https://www.legifrance.gouv.fr/affichTexte.do?cidTexte= LEGITEXT000005625281

Passariello B, Giuliano V, Quaresima S, Barbaro M, Caroli S, Forte G, Carelli G, Iavicoli I (2002) Evaluation of the environmental contamination at an abandoned mining site. Microchem J 73(1-2):245-250

Pitron G (2018) The war of rare metals: the hidden side of the green energy and digital transition, Ed. LLI

Saunier JB, Losfeld G, Freydier R, Grison C (2013) Trace elements biomonitoring in a historical mining district (les Malines, France). Chemosphere 93(9):2016-2023

Thillier Y, Losfeld G, Escande V, Dupouy C, Vasseur J-J, Debart F, Grison C (2013) Solid-phase synthesis of 5'-capped RNA with polymetallic catalysts prepared from metallophytes species. RCS Advances 3(15):5204-5212

Vila M, Basnou C, Gollasch S, Josefsonn M (2009) One hundred of the most invasive alien species in Europe. In DAISIE handbook of alien species in Europe, 3, 269-374. Dordrecht: Springer Netherlands. https://doi.org/10.1007/978-1-4020-8280-1_13

Yfantis N, Yfantis A, Giannakakis G, Gaze V (2018) Evaluation of a pilot plant for a secondary treatment of mining effluents. Desalin Water Treat 127:184-196. https://doi.org/10.5004/dwt.2018.23232

Zuryak R, Sukkariyah B, Baalbaki R, Ghanem DA (2002) Ni phytoaccumulation in Mentha aquatica L. and Mentha sylvestris L. Water Air Soil Pollut 139:355-364 